\title{
BIOPROSPECTING THERMOPHILES FOR CELLULASE PRODUCTION: A REVIEW
}

\author{
Somen Acharya*; Anita Chaudhary
}

Division of Environmental Sciences, Indian Agricultural Research Institute, New Delhi-110012, India.

\author{
Submitted: June 01, 2010; Returned to authors for corrections: November 25, 2011; Approved: June 07, 2012.
}

\begin{abstract}
Most of the potential bioprospecting is currently related to the study of the extremophiles and their potential use in industrial processes. Recently microbial cellulases find applications in various industries and constitute a major group of industrial enzymes. Considerable amount of work has been done on microbial cellulases, especially with resurgence of interest in biomass ethanol production employing cellulases and use of cellulases in textile and paper industry. Most efficient method of lignocellulosic biomass hydrolysis is through enzymatic saccharification using cellulases. Significant information has also been gained about the physiology of thermophilic cellulases producers and process development for enzyme production and biomass saccharification. The review discusses the current knowledge on cellulase producing thermophilic microorganisms, their physiological adaptations and control of cellulase gene expression. It discusses the industrial applications of thermophilic cellulases, their cost of production and challenges in cellulase research especially in the area of improving process economics of enzyme production.
\end{abstract}

Key words: Lignocelluloses, Bioethanol, cellulase, Thermophiles

\section{INTRODUCTION}

Bioprospecting is defined as the exploration of biodiversity for commercially valuable biochemical and genetic resources for achieving economic and conservation goals (28). This holds substantial promise for the development of novel compounds for food production and processes, consumer goods, public health, and environmental and energy uses. To serve these purposes, existing diversity of microorganisms can act as a resource reservoir from which individual species with special traits can be exploited $(16,26)$. Due to the environmental related issues and advances in biotechnology, many chemical processes in different Industries such as textile, leather, pulp and paper, fruits and vegetables processing and animal feed are being replaced with biocatalysts i.e. enzymes. Besides playing a crucial role in our food production and other consumer goods and services, they have recently become vital in the production of fuel for our automobiles. Enzymes can be harvested from a variety of sources i.e., animal tissue, plants and microbes. Microorganisms represent an attractive source of enzymes because they can be cultured in large quantities in a relatively short time period and as such they can produce an abundant, regular supply of desired enzyme products. Moreover,

*Corresponding Author. Mailing address: Defence Institute of High Altitude Research, DRDO, C/o 56 APO, Leh-194101, India.; E-mail: someniari@gmail.com 
microbial proteins are often more stable than enzymes of similar specificity obtained from plant or animal sources and often may be stored under less than ideal conditions for weeks without significant loss of biological activity (41). Hence most of the commercial enzymes are derived from the microorganisms (95) and are often being used in commercial processes that were previously either mechanical or cellular. Microorganisms have been used for millennia in the production of beer, wine, vinegar, yoghurt and cheese, but the number of potential and realized applications continues to grow in other industries as well viz., baking industry, leather industry, paper industry, textile industry etc. (Table 1). Many enzymes have very specific requirements of $\mathrm{pH}$ and temperature before they will function and quite often, these requirements are different from the real situations in the industrial plant. However, we now know that some microorganisms such as extremophiles can produce enzymes which can survive and function in extreme conditions, which are generally required for these applications $(34,85)$. Often the extremophiles (14) are found in such diverse and harsh environments as the thermal vents at the bottom of the ocean, in Antarctica's ice, in the thermal or hot springs, in the bellies of termites, translucent stones in the dry desert valleys of Antarctica etc. $(36,44,91)$. The third largest industrial enzyme worldwide is cellulases, because of their utility in paper recycling, cotton processing, detergent industry and food processing industry. Recently the interest in cellulases has grown across the globe, because of its importance in the production of transportation fuel, which is a driver of any economy of a country. To produce a wide variety of cellulases, both fungi and bacteria have been heavily exploited. Till now, the emphasis has been placed on fungal cellulases because of large amount of less complex extracellular cellulases which used to be more readily cloned and produced via recombination in a rapidly growing bacterial host. However, recently the shift has been towards the bacterial cellulases, because of robust bacterial growth, survival in harsh conditions of bioconversion processes, stability and presence of multi-enzyme complexes which provides increased function and synergy.

Table 1. Enzymes contributing to sustainable industrial development (41)

\begin{tabular}{lll}
\hline Industry segment & Enzymes & Chemical process replaced \\
\hline $\begin{array}{l}\text { Detergents } \\
\text { Textile }\end{array}$ & Lipases, proteases, cellulases, amylases & $\begin{array}{l}\text { Phosphates, silicates, high temperature } \\
\text { Acid, alkali, oxidizing agents, reducing agents, } \\
\end{array}$ \\
Amylases, cellulases, catalases & $\begin{array}{l}\text { water, pumis, energy, new garment manufacture } \\
\text { Acids, high temperatures }\end{array}$ \\
Backing & Amylases, pullulanases & Emulsifying agents, sodium bisulfate \\
Pulp and paper & Amylases, proteases, xylanases & Chlorine, toxic waste \\
Leather & Prlanases, mannanases & Sulfides, high temperature \\
Biocatalyst & Isomerases, lipases, reductases, acylases & Acids, organic solvents, high temperature \\
\hline
\end{tabular}

\section{Plant Biomass Structure and Enzymatic Degradation}

Plant biomass viz: agricultural residues have a great potential for the production of biofuels because of its abundance and inexpensive nature. There are multiple sources of waste from agricultural and industrial processes e.g. corn fibre, corn stover, sugarcane bagasse, rice hulls, forest residues, industrial waste, municipal solid waste and paper mill sludge. Plant cell wall is mainly constituted of cellulose, hemicellulose, lignin, water soluble sugars, amino acids and aliphatic acids, ether and alcohol-soluble constituents (e.g. fats, oils, waxes, resin and many pigments) and proteins. These components build up plant biomass. Cellulose, the most abundant polysaccharide on earth, is a highly ordered polymer of cellobiose (D-glucopyranosyl- $\beta$-1,4-D-glucopyranose), representing over $50 \%$ of the biomass. Chemically cellulose microfibrils is a $\beta-1,4$ linked anhydro D-glucose homopolymer (42) with hydroxyl group in equilateral and $\mathrm{H}$ atoms in the axial position (Fig. 1). The glycosidic linkages acting as functional groups and three hydroxyl groups together not only determine the chemical properties of cellulose but also act as a 
place for significant chemical and enzymatic reactions.

Hemicelluloses (polyoses) are the linking material between cellulose and lignin: Wood hemicelluloses are short, highly branched heteropolymers of the predominant xylose, along with glucose, mannose, galactose and arabinose, as well as different sorts of uronic acids. Depending on the predominant sugar type, the hemicelluloses are referred to as mannans, xylans or galactans. The $\mathrm{C}_{5}$ and $\mathrm{C}_{6}$ sugars, linked through 1,3, 1,6 and 1,4 glycosidic bonds and often acetylated, form a loose, very hydrophilic structure that acts as a glue between cellulose and lignin (12).

In contrast, lignin is a three-dimensional polyphenolic network built up of dimethoxylated (syringyl), monomethoxylated (guaiacyl) and non-methoxylated (phydroxyphenil) phenylpropanoid units, derived from the corresponding p-hydroxycinnamyl alcohols, which give rise to a variety of sub-units including different ether and C-C bonds. Lignin is hydrophobic and highly resistant towards chemical and biological degradation. Lignin is phenolic in nature and is deposited during lignification of the plant tissue. It gets intimately associated within the cell walls with cellulose and hemicellulose and imparts the plant an excellent strength and rigidity $(12,76)$.

Other non-structural components of plant tissues including phenols, tannins, fats and sterols, water soluble compounds such as sugars and starch, as well as proteins and ashes, usually represent less than $5 \%$ of the wood dry weight (63). Due to resistant structure of lignocellulosic biomass, efficient pretreatment technologies are needed prior to enzymatic hydrolysis. Mainly the enzymes involved in lignocellulosics hydrolysis are: Cellulases, Hemicellulases, lignin modifying enzymes and other helping proteins. In nature, a variety of enzymes (hydrolytic and oxidative) produced by a variety of fungi and bacteria, work in synergy to perform lignocellulose degradation (76). Cellulose degrading enzymes (cellulases) are widely spread in nature, predominantly produced by microorganisms, such as molds, fungi and bacteria $(8,11)$. Cellulases are the enzyme systems that hydrolyze the $\beta-1,4$ glycosidic bonds in the cellulose polymer to release glucose units (71). The biochemical transformation of cellulose molecule during biodegradation by microorganisms is catalyzed by extra cellular cellulases enzyme system.

Three components of cellulases are responsible for cellulose breakdown:

1. $\beta-1,4$ glucan glucanohydrolase (an endoglucanase) which breaks down long cellulose chain to shorter fragments.

2. $\beta-1,4$ glucan cellobiohydrolase (an exoglucanase) acting from non reducing end of cellulose chain.

3. $\beta-1,4$ glucosidase, the third component breaks down glucosidic bond of cellobiose and cellodextrins to give glucose molecules which can easily permeate into the cell (10).

In general two types of cellulase systems exists: one type consists of extracellular cellulases in filamentous fungi and in aerobic bacteria that act synergistically to degrade cellulose, while the second type is an enzyme complex called the "cellulosome," in anaerobic bacteria such as Clostridium thermocellum which consists of a nonenzymatic scaffolding protein associated with various enzymatic subunits that act synergistically to degrade cellulose and hemicellulose (64). Non complexed cellulase systems are more common and are currently most exploited for industrial applications.

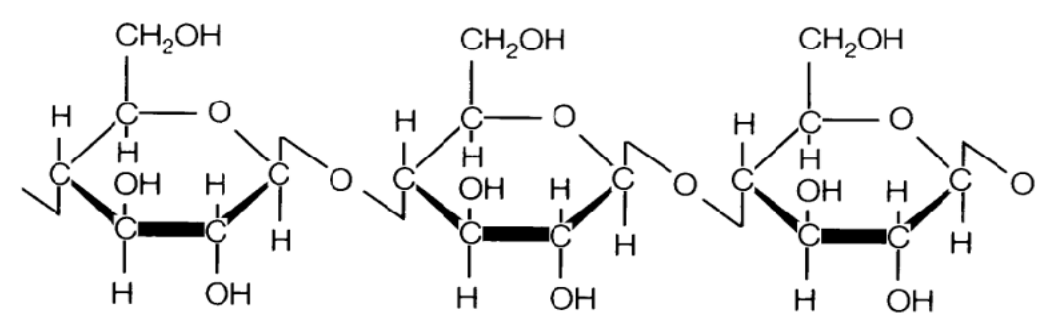

Figure 1. Cellulose structure 
Physiological and Adaptive Aspects of Thermophilic Microorganisms

To produce a wide variety of cellulases and hemicellulases, both fungi and bacteria have been heavily exploited. However, the focus has been more towards the fungi because of their capacity to excrete abundant amount of non complex cellulases and hemicellulases. Recently, this trend is shifting towards the bacteria, due to their higher growth rates, presence of more complex multi-enzymes and their presence in wide variety of environmental niches. Not only can these bacteria survive the harsh conditions, but they often produce stable enzymes which may increase rates of bioconversion processes. The cell membranes of thermophiles contain saturated fatty acids which provide a hydrophobic environment for the cell and maintain the cell rigidity at elevated temperatures (43). Further, the hyperthermophilic archae have lipids linked with ether on the cell wall and formation of a monolayer rather than bi-layer has been suggested for stability of membranes at high temperatures (24). Recently, tetraether membrane lipids were reported in a thermoacidophilic euryarchaeota Candidatus Aciduliprofundum boonei from deep sea hydrothermal vents (81). In addition to the structural adaptations of cell wall and cell membrane, DNA of thermophiles contains reverse DNA gyrase, which enhance the melting point by producing positive super coils in the DNA imparting temperature stability (59). In Sulfolobus solfataricus a small DNA binding protein, Sso7d, not only imparts thermostability to the DNA but also promotes the annealing of complementary strands above the melting point and the ATPase-dependent rescue of the aggregated proteins (18). Thermophiles are reported to have a zigzag structure of surface layer proteins which are thermostable and resist denaturation and proteolysis (52). Certain specialized proteins, known as 'chaperons', are produced by these organisms, which help to refold the proteins to their native form and restore their functions $(54,83)$. Besides the above strategies, thermophilic bacteria, actinomycetes and archae tolerate high temperatures by increased electrostatic, disulphide and hydrophobic interactions in their proteins $(53,74)$. Certain thermophilic enzymes are stabilized by certain conformational changes (29). However, certain metals, inorganic salts and substrate molecules are also reported to impart the thermostability (94). Based on the thermal behaviour of these enzymes, the Equilibrium Model has been described to reveal the effect of temperature on enzyme activity by reversible active-inactive transition states (22). Due to the increasing demand of highly thermostable industrial enzymes, certain computational algorithms and bioinformatic tools have been designed, which can predict protein rigidity and stability. Protein stabilization can be carried out by site-directed mutagenesis, and gene shuffling (39).

The fungus Hypocrea jecorina (anamorph Trichoderma reesei) produces a complete set of cellulases classified as cellobiohydrolases $(\mathrm{CBH})$ endoglucanases (EG) and $\beta-$ glucosidases. Two genes encoding CBHs, $c b h 1$ and $c b h 2$, four encoding EGs, egll, egl2, egl3, and egl5, and one encoding a $ß$-glucosidase have now been reported from this organism. The promoter regions of $c b h 1, c b h 2$, egl1 and egl2 genes has CRE1 binding sites indicating fine control of these genes by carbon catabolic repression (51). ACEII binds to the promoters of cbhI in Hypocrea jecorina (anamorph Trichoderma reesei) and is believed to control expression of cbh1, cbh2, egl1 and eg12 (6). Activator of Cellulase Expression protein I (ACEI) gene has binding sites in cbh1 promoters but it acts as a repressor of cellulase gene expression (5). Glucose repression of cellulase is supposed to be mediated through carbon catabolic repressor protein CRE1 in Hypocrea jecorina (anamorph Trichoderma reesei) (84). The promoter region of cellulases harbour binding sites for the CREI catabolic repressor protein as well as sites for the transcriptional activators including Activator of Cellulase Expression protein II (ACEII) besides CCAAT sequence, which binds general transcriptional activator complexes designated as 'HAP' proteins (69). Suto and Tomita (87) has given a detailed review on cellulase expression, in 
which a sensor enzyme is constitutively expressed which hydrolyzes cellulose into oligosaccharides that enter the bacterium and activate the expression of the cellulase genes.

\section{Cellulase Producing Thermophiles}

Cellulolytic fungi: The cellulolytic fungus Trichoderma sp. was considered as the best source of cellulases (79), however, the major bottleneck with Trichoderma cellulases is that they produce very low $\beta$-glucosidase activity in culture supernatants and the enzyme is subject to product inhibition (50). Mandels (62) observed that some species of thermophilic fungi degraded cellulose rapidly but that their culture filtrates had low cellulase activity. This was contradicted by reports that the thermophilic fungi Sporotrichum thermophile (20) and Talaromyces emersonii (30) produced cellulase activity nearly comparable to that of the mesophilic fungus Hypocrea jecorina (anamorph Trichoderma reesei). Characterization of Hypocrea jecorina (anamorph Trichoderma reesei) cellulase and xylanase promoters has recently been evaluated by Rahman et al. (77). Cellulolytic rates of some thermophilic fungi Chaetomium thermophile, Sporotrichum thermophile and Thermoascus aurantiacus has been observed to be two or three times greater than that of Trichoderma viridae (89). Chellapandi and Jani (17) studied on production of endoglucanase by the native strains of Streptomyces isolates in submerged fermentation in Brazil.

In general, crystalline cellulose has been found to be a superior carbon source for cellulase production in thermophilic fungi than its amorphous or impure forms $(31,78)$ except Thermoascus aurantiacus (47), Humicola insolens (40) and $H$. grisea var. thermoidea which showed high cellulase and xylanase activities even on hemicellulosic substrates without cellulose. Like the mesophilic fungi, the thermophilic fungi produced multiple forms of the cellulase components.

Cellulolytic Bacteria: In nature, fungi tend to produce more cellulases than bacteria, however, cellulases produced by bacteria cellulases is being met by production methods using are better catalyst as they encounter less feedback inhibition. submerged fermentation (SmF) processes and widely studied
Moreover, not only bacteria grow rapidly compared to fungi, allowing for higher recombinant production of enzymes. The capacity of bacteria inhabiting wide variety of environmental niches such as high temperature, alkaline $\mathrm{pH}$, and acidic $\mathrm{pH}$ help these strains to produce biocatalysts which are stable under harsh conditions found in the bioconversion processes leading to increase rates of hydrolysis and finally efficient product recovery. The bacterial cellulases have very high activities against crystalline celluloses like cotton or avicel and are also more thermostable and are able to perform in an alkaline $\mathrm{pH}$ in comparison to fungal cellulases $(13,61,97)$. The cellulolytic property has been reported in Bacillus strains (65) and in thermophilic anaerobic bacterium Clostridium thermocellum (66). Fangdong (27) isolated thermophilic cellulolytic bacteria by using three different kinds of medium and determined its enzyme activity. Acharya and Chaudhary (2) also isolated thermophilic cellulolytic Bacillus strains from hot spring, India and reported $60^{\circ} \mathrm{C}$ for their optimal activity. Thermostable cellulases of archaeal origin showing optimal activity at 102$105^{\circ} \mathrm{C}$ have been isolated from Pyrococcus furiosus (48) and Pyrococcus horikoshii (3). Sulfolobus solfataricus MT4, Sulfolobus acidocaldarius and Sulfolobus shibatae have also been shown to produce significant amount of $\beta$-glucosidases (35). Highly thermostable cellulases acting at $95^{\circ} \mathrm{C}, \mathrm{pH} 6.0$ and 7.0 has been reported from Thermotoga maritima MSB8 (15). The other species of the same organism i.e. Thermotoga sp. FjSS3-B1 also produced highly thermostable cellobiose which was active at $115^{\circ} \mathrm{C}$ at $\mathrm{pH}$ 6.8-7.8 (80). Endocellulase, with the ability to hydrolyze microcrystalline cellulose, was isolated from the extremely thermophilic bacterium Anaerocellum thermophilum (100) and maximal activity of this enzyme was observed at $\mathrm{pH}$ 5.0-6.0 and $85-95^{\circ} \mathrm{C}$.

\section{Fermentative Processes for Microbial Cellulase Production}

Currently, industrial demand for microbial production of 
organism used generally genetically modified strains of Hypocrea jecorina (anamorph Trichoderma reesei). Although the high cost of production in SmF systems due to increased fermentation time with low productivity, has resulted in a shift towards the solid state fermentation (SSF) systems but the advantage of better monitoring and handling are still associated with the submerged cultures (86). Though there are reports on cellulases production by SSF, the large scale commercial processes are still using the proven technology of $\mathrm{SmF}$ because the SSF is still non competitive. The appropriate technology, operation controls and improved bioreactor design may make it viable e.g. the enzyme in SSF crude product after concentration can be directly use in agro-biotechnological applications viz. silage or feed additive, ligno-cellulosic hydrolysis, and for processing of natural fiber. Solid state fermentation (SSF) may become a competitive method for the production of cellulases as it offers numerous advantages such as high productivity, relatively high concentrations of the products and less effluent generation. Tengerdy (92) compared cellulase production in SmF and SSF systems and indicated that there was a 10 fold reduction in the production cost in SSF than SmF. Pandey et al.
(73) also describes the tremendous potential of SSF for the production of various enzymes of industrial importance and their direct agro-biotechnological applications as silage or feed additive, ligno-cellulosic hydrolysis and natural fibre (e.g. jute) processing. Da-Silva et al. (23) also produced xylanase and CMCase on SSF in different residues by Theroascus aurantiacus. There has been attempts to produce cellulase through fed batch instead of batch processes which helps to overrides the repression caused by accumulation of reducing sugars.

\section{Industrial Uses of Thermophilic Cellulases}

Thermophilic enzymes are ideal biocatalysts for modern biotechnology because of their thermostability (38) and better yields under extreme operational conditions (4). The wide range of applications of thermophilic cellulases is being listed in Table 2. Potential applications are in food, animal feed, textile, fuel, chemical industries, paper and pulp industry, waste management, medical/pharmaceutical industry, protoplast production, genetic engineering and pollution treatment (90).

Table 2. Bioconversion reactions and applications of thermostable enzymes (38)

\begin{tabular}{|c|c|c|c|}
\hline Enzyme & $\begin{array}{c}\text { Temperature range } \\
\left({ }^{\circ} \mathrm{C}\right)\end{array}$ & Bioconversions & Applications \\
\hline$\alpha$-amylase (bacterial) & $90-100$ & Starch to dextrose syrups & Starch hydrolysis, brewing, baking, detergents \\
\hline$\alpha$-amylase (fungal) & $50-60$ & Starch to dextrose syrups & Production of maltose \\
\hline Pullulanase & $50-60$ & Starch to dextrose syrups & Production of glucose syrups \\
\hline Xylanase & $45-65,105 \mathrm{a}$ & Craft pulp to xylan+lignin & Pulp and paper industry \\
\hline Chitinase & $65-75 b$ & $\begin{array}{l}\text { Chitin to chitobiose } \\
\text { Chitin to N-acetyl glucosamine } \\
\text { (chitibiase) } \\
\text { N-acetyl glucosamine to } \\
\text { glucosamine (deacetylation) } \\
\text { Chitin to chitosan (deacetylase) }\end{array}$ & $\begin{array}{l}\text { Food, cosmetics, pharmaceuticals, } \\
\text { agrochemicals }\end{array}$ \\
\hline Cellulase & $45-55,95 c$ & Cellulose to glucose & $\begin{array}{l}\text { Cellulose hydrolysis, polymer } \\
\text { degradation in detergents }\end{array}$ \\
\hline Protease & $65-85$ & $\begin{array}{l}\text { Protein to amino acids and } \\
\text { peptides }\end{array}$ & $\begin{array}{l}\text { Baking, brewing, detergents, leather } \\
\text { industry }\end{array}$ \\
\hline Lipase & $30-70$ & $\begin{array}{l}\text { Fat removal, hydrolysis, } \\
\text { interesterification, alcholysis, } \\
\text { aminolysis }\end{array}$ & $\begin{array}{l}\text { Dairy, oleo chemical, detergent, } \\
\text { pulp, pharmaceuticals, cosmetics } \\
\text { and leather industry }\end{array}$ \\
\hline DNA polymerase & $90-95$ & DNA amplification & Genetic engineering/PCR \\
\hline
\end{tabular}

a Xylanase from Thermotoga sp.

b Within this range enzyme activity was high.

c Cellulases from Thermotoga sp. 
Food Processing: Thermophilic cellulases play a primary role in food biotechnology. Macerating enzymes complex (cellulases, xylanases and pectinases) is being used for extraction and clarification of fruit and vegetable juices $(9,70)$. Their use improves cloud stability and texture and decrease viscosity of the nectars and purees from tropical fruits. By infusion of enzymes such as pectinases and $\beta$-glucosidases, texture, flavour and aroma properties of fruits and vegetables can be improved. The mixture of pectinases, cellulases and hemicellulases can also be used for improved extraction of olive oil.

Textile Processes: The textile industry uses thermophilic cellulases for creating the stone washed look in jeans, biopolishing of cotton and other cellulosic fabrics. Commonly the thermophilic cellulases are used in the stone washing of jeans to make them appear faded (93, 94). During the stone washing process, cellulases act on the cotton fabric and break off the small fiber ends on the yarn surface, thereby loosening the dye, which is easily removed in the wash cycle. These enzymes are also being added in the detergents for decreasing the discolouration and fuzzing effects caused by numerous washes $(21,99)$. During repeated washing most cotton blended garments, tend to become fluffy and dull, due to the presence of partially detached microfibrils on the surface. The cellulases present in these detergents can remove these microfibrils and restore a smooth surface and original colour to the garments. Svetlana et al. (88) used the cellulases for treatment of raw cotton fibers i.e. non woven fabrics.
Paper Processing: In the Pulp and Paper mill, mechanical pulping process of the woody materials lead to bulky and stiffed pulp, however the pulp prepared with thermophilic cellulases not only leads to energy saving but also improves the mechanical strength of the pulp (75). Besides this cellulases have also been shown to enhance the bleachability of the pulp (25) and deinking of different types of paper wastes. The main benefit which is being drawn from the biobleaching is that of less alkali usage, reduction in fine particles in pulp and improved fiber brightness (25, 68). Thus the use of cellulases alone or in combination with xylanases has not only improved the overall performance of the paper mills but they can also be used in preparation of easily biodegradable cardboard, manufacturing of paper towels and sanitary paper.

Ethanol Fuel Production: Two main approaches have been developed in parallel for conversion of lignocellulose to ethanol "acid based" and "enzyme based" (32, 37, 57). Biomass hydrolysis, i.e. the depolymerization of the biomass polysaccharides to fermentable sugars, must be performed via environmentally friendly and economically feasible technologies (60). The enzyme based ethanol production (Fig. 2) has an advantage over chemical procedure, because of its higher conversion efficiency, the absence of substrate loss due to chemical modifications and the use of more moderate and noncorrosive physical-chemical operating conditions. Atsushi et al. (7) directly produced ethanol from barley $\beta$-glucan by shake yeast using Aspergillus oryzae $\beta$-glucosidase and endoglucanase.

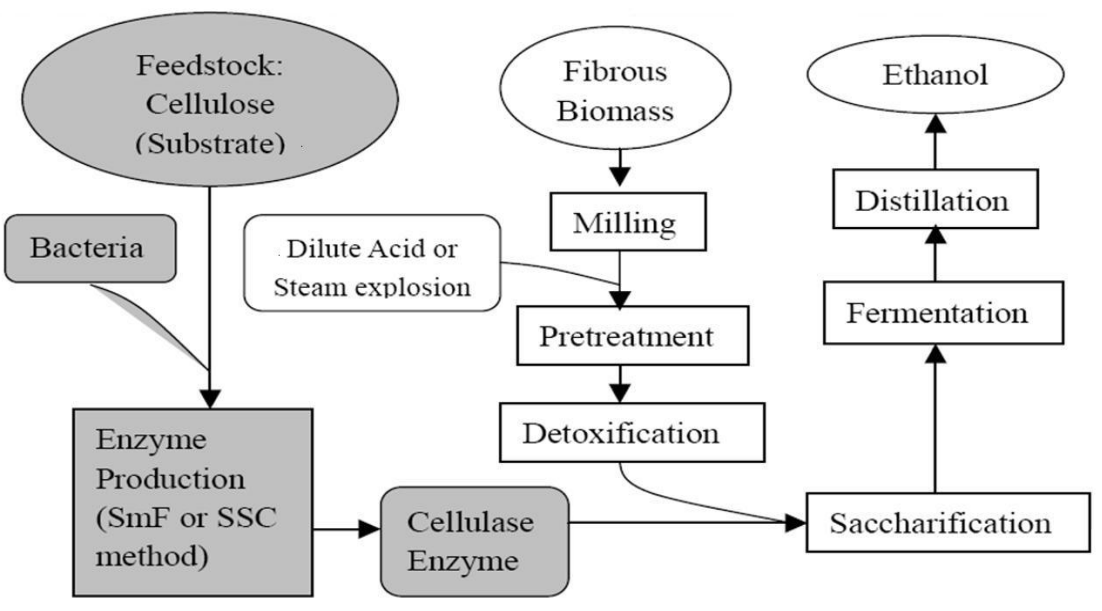

Figure 2. Enzyme production component within the ethanol production 


\section{Cellulase Production Costs and Challenges}

The search for greener fuels, as well as more environmental friendly technologies in different industries has renewed the interests in cellulases. However, the enzyme cost is considered to be a major impediment in its extensive commercialization. Production of enzymes by microorganisms offers enormous advantages over the conventional chemical techniques, as they can be produced in copious amounts by established fermentation techniques. Cellulase yields depend on a complex interrelationship of variety of factors such as inoculums size (carbon source and cellulose quality), $\mathrm{pH}$ value, temperature, presence of inducers, medium additives, aeration and incubation period etc. (46). Ghosh and Ghosh (33) studied the relationship between growth conditions and cellulase productions. For enzyme to be commercially successful, yield of $1100 \mathrm{FPUL}^{-1} \mathrm{~h}^{-1}$ (FPU = Filter paper unit) is needed which can be obtained from the culture with a growth rate of $70 \mathrm{~g} \mathrm{~L}^{-1} \mathrm{~h}^{-1}$ (12). This high growth rate can be achieved if the microorganisms show any one or both of the following properties:

i) a high enhanced capacity for cellulase production;

ii) An ability to produce enzymes with a high specific activity

Moreover, the amount, nature and composition of lignocellulosic substrates (Table 3) and sugars present in medium also affect the cellulase biosynthesis (67). Acharya et al. (1) studied the optimization for cellulase production by Aspergillus niger using saw dust as substrate and different fungal species producing cellulases were used by Khan et al. (49) for bioconversion of rice straw. Ojumu et al. (72) reported on cellulase production by Aspergillus flavus by using saw dust, bagasse and corn cobs as substrates. The other substrates which also can be used are corn cobs, wheat straw, sugarcane bagasse, aspen wood and waste from newspaper industry (58). Cellulase is an inducible enzyme and Sophorose, is an indispensable inducer of cellulase activity. In order to lower the production costs of cellulases, cheaper carbon and nitrogen sources are desired. Recently agricultural and other waste residues are being used for cellulase production, however, due to the high cost of the utilization process, the commercialization of this technology has been hampered (56). The biomass needs to be pre-treated to expose the cellulose fibre to the enzymes and high concentrations of enzymes are required which accounts for more than $50 \%$ of the ethanol production cost (96). Three different approaches have been proposed to reduce the cost of cellulase: (i) improve on-site production of cellulase; (ii) optimized reconstitution of cellulase components from different sources into a more effective artificial cellulase system and (iii) development of improved ethanologenic biocatalysts which supply a portion of the cellulase needed for the direct microbial conversion of cellulose into ethanol. These improved enzyme preparations must present different characteristics, such as higher catalytic efficiency, increased stability at elevated temperatures and certain $\mathrm{pH}$ and higher tolerance to end-product inhibition (98). For lowering the cost of cellulase production different strategies such as development of recombinant organisms, metabolic engineering and native engineering etc. can be adopted (55) (Fig. 3). It is well recognized that the economic viability of biomass ethanol depends on the enzyme cost contribution. Novozymes the largest enzyme supplier has already obtained a $40 \%$ reduction in cellulase enzyme costs and now they can supply enzymes at a cost of US\$0.5 per gallon of ethanol produced. At this price the conversion processes has started looking attractive. However, to support an economical and robust biorefinery industry, a further decrease is still necessary to US\$ 0.10 /gallon (or $0.026 / \mathrm{L}$ ). Data from the industry indicate that the present industrial enzymes cost US\$2.24/gallon (US\$ 0.59/L). The capital costs can be lowered by different routes of improving the enzyme efficiencies which involves the development of enzymes with more heat tolerance and higher specific activities, and better corresponding enzymes for different plant cell-wall polymers. 
Table 3. Percentage composition of different lignocellulosic substances

\begin{tabular}{llll}
\hline Lignocellulosic substances & Cellulose & Hemicellulose & Lignin \\
\hline Coniferous wood & $40-50$ & $20-30$ & $25-35$ \\
Deciduous wood & $40-50$ & $30-40$ & $15-20$ \\
Bagasse & 37 & 28 & 21 \\
Nut shells & $25-30$ & $25-30$ & $30-40$ \\
Corn cobs & 45 & 35 & 15 \\
Corn stalks & 35 & 25 & 35 \\
Wheat straw & 30 & 50 & 15 \\
Rice straw & 35 & 35 & 10 \\
\hline
\end{tabular}

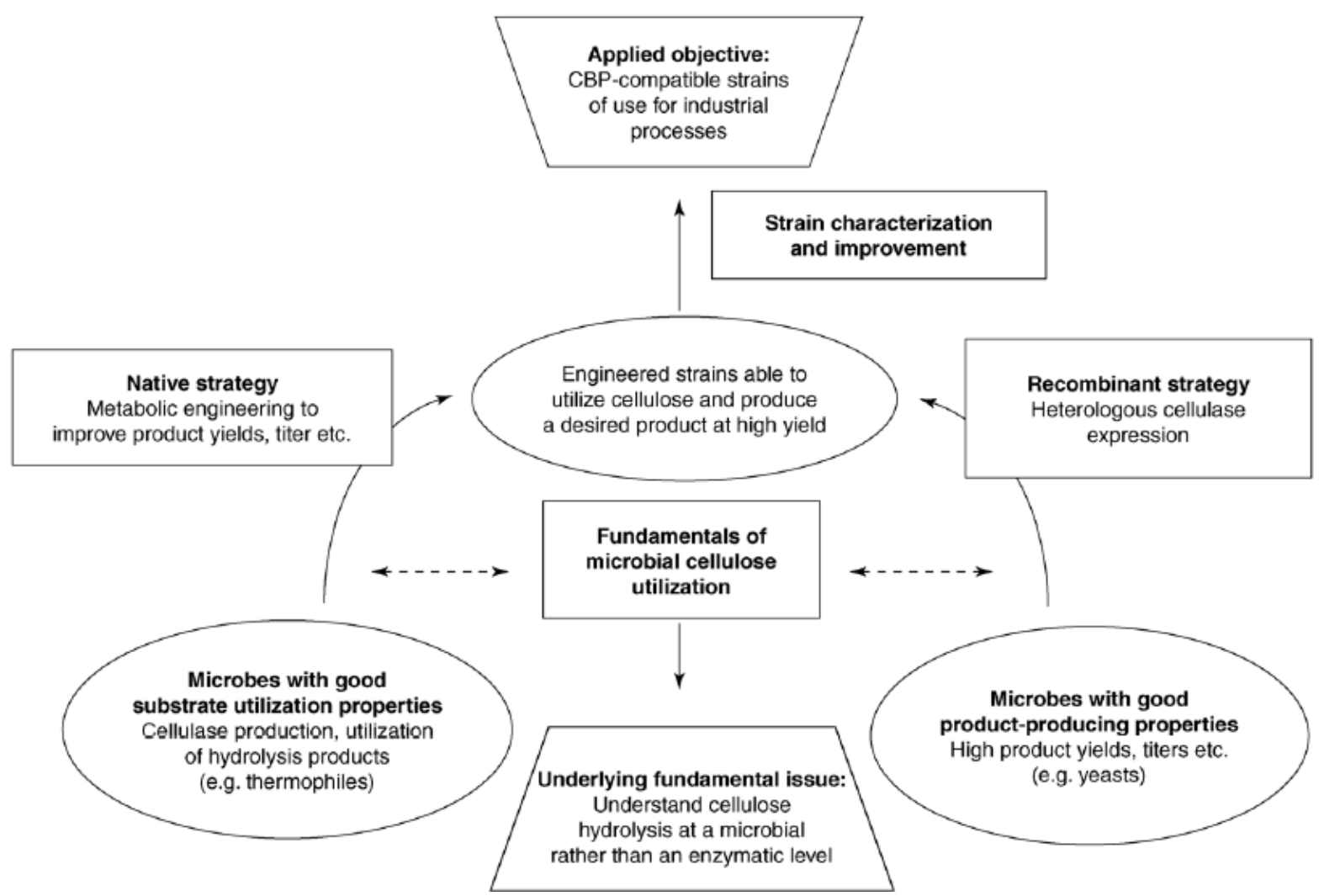

Figure 3. Organism development strategies and related fundamentals (55)

\section{Cellulase Market}

Most of the industrial enzymes $(60 \%)$ are produced in Europe, whereas the remaining $40 \%$ come from the United States and Japan. Presently, the world enzyme market is estimated to be worth US\$ 4 billion, whereof approximately $60 \%$ are attributed to industrial enzymes, with a rising tendency of $5.7 \%$ per year (19). In this context, hydrolases represent $75 \%$ of the industrial enzymes and carbohydrases are the second largest group of industrial enzymes. Cellulases contribute to $8 \%$ of the worldwide industrial enzyme demands. During the period 2004-2014 an increase of approximately $100 \%$ in use of cellulases as a special enzyme has been projected (19). Countries such as China, India, South Korea and Taiwan, which have recently emerged as industrialized 
manufacturing centers with strong national research and development programs, will play a much larger role in the world market.

\section{CONCLUSIONS}

After decades of research on lignocellulosic biomass utilization, it is now considered that enzyme based technologies for biomass conversions are most efficient, cost effective and environment friendly. Considerable progress has been made in search of extremophiles, yet their true diversity, has not yet been fully explored. Thermostable cellulases isolated from these organisms have shown their potential under conditions that are appropriate for bioconversion processes which have role in industries. The future challenges for cellulases production include technologies for cellulosic biomass pretreatment for better microbial attack, processes for cost effective production of cellulases and finally organism development strategies to improve the properties of enzyme to increase their specific activities, process tolerance and thermal stability.

\section{REFERENCES}

1. Acharya, P.B.; Acharya D.K.; Modi, H.A. (2008). Optimization for cellulase production by Aspergillus niger using saw dust as substrate. Afr. J. Biotechnol., 7 (22), 4147-4152.

2. Acharya, S.; Chaudhary, A. (2011). Effect of nutritional and environmental factors on cellulases activity by thermophilic bacteria isolated from hot spring. J. Sci. and Ind. Res., 70, 142-148.

3. Ando, S.; Ishida, H.; Kosugi, Y.; Ishikawa, K. (2002). Hyperthermostable endoglucanase from Pyrococcus horikoshii. Appl. Environ. Microbiol., 68, 430-433.

4. Andrade, C.M.M.C.; Nei P Jr.; Antranikian, G. (1999). Extremely thermophilic microorganisms and their polymerhydrolytic enzymes. Braz. J. Microbiol., 30, 287-298.

5. Aro, N.; Ilmen, M.; Saloheimo, A.; Penttila, M. (2002). ACEI is a repressor of cellulase and xylanase genes of Trichoderma reesei. Applied Environ. Microbiol., 69, 56-65.

6. Aro, N.; Saloheimo, A.; Ilmen, M.; Penttila, M. (2001). ACEII, a novel transcriptional activator involved in regulation of cellulase and xylanase genes of Trichoderma reesei. J. Biol. Chem., 276, 24309-24314.

7. Atsushi, K.; Hiroki, B.; Masahiko, K.; Michiko, K.M.; Kouichi, K.; Hiroshi, S.; Yoji, H.; Akihiko, K.; Mitsuyoshi, U. (2008). Direct ethanol production from barley $\beta$-glucan by shake yeast displaying Aspergillus oryzae $\beta$-glucosidase and endoglucanase. J. Biosci. Bioengg, 105(6), 622-627.

8. Beguin, P.; Aubert, J.P. (1992). Cellulase. In: Lederberg J (ed) Encyclopedia of microbiology 1, Academic Press, NY, p. 467-477.

9. Bhat, M.K. (2000). Cellulases and related enzymes in biotechnology. Biotechnol. Adv., 18, 355-383.

10. Bhat, M.K.; Bhat, S. (1997). Cellulose degrading enzymes and their potential industrial applications. Biotechnol. Adv., 15, 583-620.

11. Bhat, M.K.; Hazlewood, G.P. (2001). Enzymology and other characteristics of cellulases and xylanases. In: Bedford M, Partridge G (eds) Enzymes in farm animal nutrition. CABI, Bradford, p. 11-57.

12. Bon, E.P.S.; Ferrara M.A. (2007). Bioethanol production via enzymatic hydrolysis of cellulosic biomass on "The role of agricultural biotechnologies for production of bioenergy in developing countries", FAO seminar, Rome.

13. Bon, E.P.S.; Picataggio, S. (2002). Enzyme and Microbial Biocatalysis. Appl. Biochem. Biotechnol., 163, 98-100.

14. Brock, T. D. (1986). Introduction: An overview of the thermophiles. In Thermophiles: General, Molecular and Applied Microbiology (ed. Brock, T. D.), John Wiley \& Sons, N Y, p. 1-16.

15. Bronnenmeier, K.; Kern, A.; Libel, W.; Staudenbauer, W. (1995). Purification of Thermotoga maritema enzymes for the degradation of cellulose materials. Appl. Environ. Microbiol., 61, 1399-1407.

16. Bull, A.T.; Ward A.C.; Goodfellow, M. (2000). Search and Discovery Strategies for Biotechnology: the Paradigm Shift. Microbiol. Mol. Biol. Rev., 46(3), 573-606

17. Chellapandi, P.; Jani, H.M. (2008). Production of endoglucanase by the native strains of Streptomyces isolates in submerged fermentation. Braz. J. Microbiol. 39, 122-127.

18. Ciaramella, M.; Pisani, F.M.; Rossi, M. (2002). Molecular biology of extremophiles: recent progress on the hyperthermophilic archaeon Sulfolobus. Antonie Van Leeuwenhoek, 81, 85-97.

19. Costa, R.B.; Silva, M.V.A.; Freitas, S.P.; Alves, F.C.; Leitão, V.S.F.; Lacerda, P.S.B.; Ferrara, M.A.; Bon, E.P.S. (2007). Enzimas industriais e especiais: mercado nacional e internacional. In Enzimas em Biotecnologia: Produção, Aplicações e Mercado, Guanabara Koogan, Rio de Janeiro.

20. Coutts, A.D.; Smith. R.E. (1976). Factors influencing the production of cellulases by Sporotrichum thermophile. Appl. Environ. Microbiol., 31, 819-825.

21. Csiszar, E.; Losonczi, A.; Szakacs, G.; Rusznak, I.; Bezur, L.; Reicher, J. 
(2001). Enzymes and chelating agent in cotton pretreatment. $J$. Biotechnol., 89, 271-279.

22. Daniel, R.M.; Danson, M.J.; Eisenthal, R.; Lee, C.K.; Peterson, M.E. (2008). The effect of temperature on enzyme activity: new insights and their implications. Extremophiles, 12, 51-59.

23. Da-Silva, R.; Lago, E.S.; Merheb, C.W.; Macchione, M.M.; Park, Y.K.; Gomes, E. (2005). Production of xylanase and CMCase on solid-state fermentation in different residues by Theroascus aurantiacus MIEHE. Braz. J. Microbiol., 36, 235-241.

24. De Rosa, M.; Morana, A.; Riccio, A.; Gambacorta, A.; Trincone, A.; Incani, O. (1994). Lipids of the archaea: a new tool for bioelectronics. $J$. Biosen. Bioelectro., 9, 669-675.

25. Dienes, D.; Egyhazi, A.; Reczey, K. (2004). Treatment of recycled fiber with Trichoderma cellulases. Industrial Crops and Products, 20, 11-21.

26. Egorova, K.; Antranikian, G. (2005). Industrial relevance of thermophilic Archaea. Curr Opin. Microbiol., 8, 649-655.

27. Fangdong, Z. (2008). Study on the isolation of thermophilic cellulolytic bacteria by using 3 kinds of medium and the determination of its enzyme activity. J. Anhui Agri. Sci., 36 (15), 6171-6172.

28. Firn, R.D. (2003). Bioprospecting-Why is it so unrewarding? Biodiversity and Conservation, 12, 207-216.

29. Fitter, J. (2003). A measure of conformational entropy change during thermal protein unfolding using neutron spectroscopy. Biophysical Journal, 84 (6), 3924-3930.

30. Folan, M.A.; Coughlan, M.P. (1978). The cellulase complex in the culture filtrate of the thermophyllic fungus, Talaromyces emersonii. Int. J. Biochem., 9, 717-722.

31. Fracheboud, D.; Canevascini, G. (1989). Isolation, purification, and properties of the exocellulase from Sporotrichum (Chrysosporium) thermophile. Enz. Microb. Technol., 11, 220-229.

32. Galbe, M.; Zacchi, G. (2002). A review of the production of ethanol from softwood. Appl. Microbiol. Biotechnol., 59, 618-628.

33. Ghosh, B. K.; Ghosh, A. (1991). Degradation of cellulose by fungal cellulase. In Microbial degradation of Natural Products, ed. G. Winkellmann. N Y, VCH, p. 83-126.

34. Gomes, J.; Steiner, W. (2004). The biocatalytic potential of extremophiles and extremozymes. Food Technol. Biotechnol., 42(4), 223-235.

35. Grogan, W. (1991). Evidence that $\beta$-galactosidase of Sulfolobus solfactoricus is only one of several activities of a thermostable $\beta$-Dglycosidase. Appl. Environ. Microbiol., 57, 1644-1649.

36. Gullo, V.P.; McAlpine, J.; Lam, K.S.; Baker, D.; Petersen, F. (2006). Drug discovery from natural products. J. Ind. Microbiol. Biotechnol., 33(7), 523-531

37. Hahn-Hägerdal, B.; Galbe, M.; Gorwa-Grauslund, M.F.; Lidén, G.; Zacchi, G. (2006). Bio-ethanol-the fuel of tomorrow from the residues of today. Trends Biotechnol., 24 (12), 549-556.

38. Haki, G.D.; Rakshit, S.K. (2003). Developments in industrially important thermostable enzymes: a review. Bioresour. Technol., 89, 1734.

39. Hayashi, K.; Ying, L.; Singh, S.P.; Kaneko, S.; Nirasawa, S.; Shimonishi, S.; Kawata, Y.; Imoto, T.; Kitaoka, M. (2001). Improving enzyme characteristics by gene shuffling: application to $\beta$-glucosidase. $J$. Mol. catalysis B: Enzyamatic, 11, 811-816.

40. Hayashida, S.; Yoshioka, H. (1980). Production and purification of thermostable cellulases from Humicola insolens YH-8. Agric. Biol. Chem., 44, 1721-1728.

41. Headon, D.R.; Walsh, G. (1994). The industrial production of enzymes. Biotechnol. Adv., 12(4), 635-646.

42. Heck, J.X.; Hertz, P.F.; Ayub, M.A.Z. (2002). Cellulase and xylanase production by isolated Amazon Bacillus strains using soya been industrial residue based solid-state cultivation. Braz. J. Microbiol., 33, 213-218.

43. Herbert, R.; Sharp, R. (1992). Molecular Biology and Biotechnology of Extremophiles. Chapman and Hall.

44. Hoyoux, A.; Blaise. V.; Collins, T.; D’amico, S.; Gratia, E.; Huston, A.L.; Marx, J.C.; Sonan, G.; Zeng, Y.; Feller, G.; Gerday, C. (2004). Extreme catalysts from low temperature environments. J. Biosci. Bioengg., 98(5), 317-330.

45. Ilmen, M.; Saloheimo, A.; Onnela, M.A.; Penttila, M.E. (1997). Regulation of cellulase gene expression in the filamentous fungus Trichoderma reesei. Appl. Environ. Micobiol., 63, 1298-1306.

46. Immanuel, G.; Dhanusha, R.; Prema, P.; Palavesam, A. (2006). Effect of different growth parameters on endoglucanase enzyme activity by bacteria isolated from coir retting effluents of estuarine environment. Int. J. Env. Sc. Technol., 3, 25-34.

47. Kawamori, M.; Takayama, K.I.; Takasawa, S. (1987). Production of cellulases by a thermophilic fungus Thermoascus aurantiacus A-131. Agric. Biol. Chem., 51, 647-654.

48. Kengen, S.; Luesink, E.; Stams, A.; Zehnder, A. (1993). Purification and characterization of an extremely thermostable $\beta$-glucosidase from the hyperthermophilic archaeon Pyrococccus furiosus. Eur. J. Biochem., 213, 305-312.

49. Khan, M.D.M.H.; Ali, S.; Fakhru, A.; Alam, M.D.Z. (2007). Use of fungi for the bioconversion of rice straw into cellulase enzyme. $J$. Environ. Sci. Health., Part B. 42, 381-386.

50. Knapp, J.S. (1985). Biodegradation of cellulose and lignins. Comprehen. Biotechnol., 4, 835.

51. Kubicek, C.P.; Penttila, M.E. (1998). Regulation of production of plant polysaccharide degrading enzymes by Trichoderma, In Trichoderma and Gliocladium, Vol. 2G, edited by E Harman and C. P. Kubicek (Taylor \& Francis Ltd., London), p. 49-72. 
52. Kumar, S.; Nussinov, R. (2001). How do thermophilic proteins deal with heat? Cell. Mol. Life Sci., 58, 1216-1233.

53. Ladenstein, R.; Ren, B. (2006). Protein disulfides and protein disulfide oxidoreductases in hyperthermophiles. Federation of European Biochem. Soc. J., 273(18), 4170-4185.

54. Laksanalamai, P.; Robb, F.T. (2004). Small heat shock proteins from extremophiles. Extremophiles, 8, 1-11.

55. Lee, R.L.; Willem, H.V.Z.; John, E.M.; Mark, L. (2005). Consolidated bioprocessing of cellulosic biomass: an update. Curr. Opinion Biotechnol., 16, 577-583.

56. Lee, Y.J.; Kim, B.K.; Lee, B.H.; Jo, K.I.; Lee, N.K. (2007). Purification and characterization of cellulase produced by Bacillus amyoliquefaciens DL-3 utilizing rice hull. College Nat. Res. Life Sci., 840, 604-714.

57. Licht, F.O. (2006).World ethanol markets: The outlook to 2015, Tunbridge Wells, Agra Europe Special Report, UK.

58. Liming, X.; Xueliang, S. (2003). High yield cellulase production by Trichoderma reesei ZU-02 on corn cob residue. Bioresource Technol., 91, 259-262.

59. Lopez, G. (1999). DNA supercoiling and temperature adaptation: a clue to early diversification of life. J. Mol. Evolution, 46, 439-452.

60. Lynd, L.R.; Van Zyl, W.H.; McBride, J.E.; Laser, M. (2005). Consolidated bioprocessing of cellulosic biomass: an update. Curr. Opinion Biotechnol., 16, 577-583.

61. Macedo, J.M.B.; Gottschalk, L.M.F.; Bon, E.P.S. (1999). Lignin peroxidase and protease production by Streptomyces viridosporus T7A in the presence of calcium carbonate, nutritional and regulatory carbon sources. Appl. Biochem. Biotechnol., 77-79, 735-744.

62. Mandels, M. (1975). Microbial sources of cellulase. Biotechnol. Bioeng. Symp., 5:81-105.

63. Martinez, A.T.; Speranza, M.; Ruiz-Duenas, F.J.; Ferreira, P.; Camarero, S.; Guillen, F.; Martinez, M.J.; Gutierrez, A.; del Rio, J.C. (2005) Biodegradation of lignocellulosics: microbial, chemical, and enzymatic aspects of the fungal attack of lignin. International Microbiol., 8, 195 204.

64. Mathew, G.M.; Sukumaran, R.K.; Singhania, R.R.; Pandey, A. (2008). Progress in research on fungal cellulases for lignocellulose degradation. J. Sci. Indus. Res., 67, 898-907.

65. Mawadza, C.; Hatti-Kaul, R.; Zvauya, R.; Mattiasson, B. (2000). Purification and characterization of cellulases produced by two Bacillus strains. J. Biotechnol. 83, 177-187.

66. Mori, Y. (1992). Comparison of the cellulolytic systems of Clostridium thermocellum YMA and JW20. Biotechnol. Lett., 14, 131-136.

67. Moriera, A.R.; Phillips, J.A.; Humphrey, A.E. (1981). Utilization of carbohydrates by Thermomonospora $s p$. Grown on glucose, cellobiose and cellulose. Biotech. Bioengg., 23, 1339-1347

68. Nakamura, H.; Kubota, H.; Kono, T.; Isogai, A.; Onabe, F. (2001).
Modification of pulp properties by cellulase treatment and application of cellulase to wastepaper deinking and mechanical pulp refining. In: 68th Pulp and Paper Research Conference. Proceedings of the Pulp and Paper Research Conference, 18-19/06, Japan, p. 2-5.

69. Narendja, F.M.; Davis, M.A.; Hynes, M.J. (1999). An CF, the CCAAT binding complex of Aspergillus nidulans, is essential for the formation of a DNAse I-hypersensitive site in the 50 region of the amdS gene. Mol. Cell Biol., 19, 6523-6531.

70. Niehaus, F.; Bertoldo, C.; Kahler, M.; Antranikian, G. (1999). Extremophiles as a source of novel enzymes for industrial applications. Appl. Microbiol. Biotechnol., 51, 711-729.

71. Nishida, Y.; Suzuki, K.I.; Kumagai, Y.; Tanaka, H.; Inoue, A.; Ojima, T. (2007). Isolation and primary structure of a cellulase from the Japanese sea urchin Strongylocentrotus nudus. Biochimie., 1-10.

72. Ojumu, T.V.; Solomon, B.O.; Betiku, E.; Layokun, S.K.; Amigun, B. (2003). Cellulase production by Aspergillus flavus L. isolate NSPR 101 fermentaed in sawdust, bugasse and corn cob. Afr. J. Biotech., 2, 150 152.

73. Pandey, A.; Selvakumar, P.; Soccol, R.C.; Nigam, P. (1999). Solid state fermentation for the production of industrial enzymes. Current Sci., 77(1), 149-162.

74. Pebone, E.; Limauro, D.; Bartolucci, S. (2008). The machinery for oxidative protein folding in thermophiles. Antioxid Redox Signal, 10(1), 157-169.

75. Pelach, M.A.; Pastor, F.J.; Puig, J.; Vilaseca, F.; Mutje, P. (2003). Enzymic deinking of old newspapers with cellulase. Process Biochem., 38, 1063-1067.

76. Perez, J.; Munoz-Dorado, J.; Rubia, T.; Martinez, J. (2002). Biodegradation and biological treatments of cellulose, hemicellulose and lignin: an overview. International Microbiol., 5, 53-63.

77. Rahman, Z.; Shida, Y.; Furukawa, T.; Suzuki, Y.; Okada, H.; Ogasawara, W.; Morikawa, Y. (2009). Evaluation and Characterization of Trichoderma reesei cellulase and xylanase promoters. Appl. Microbiol. Biotechnol. 82(5), 899-908.

78. Rao, U. S.; Murthy, S. K. (1988). Purification and characterization of a $\beta$-glucosidase and endocellulase from Humicola insolens. Indian J. Biochem. Biophys., 25, 687-694.

79. Reese, E.T.; Mandels, M. (1964). Enzymatic hydrolysis of cellulose and its derivatives. Methods in carbohydrate chem., 3, 139-142.

80. Ruthersmith, L.; Daniel, R. (1991). Thermostable cellobiohydrolase from the thermophilic eubacterium Thermotoga sp. Strain FjSS3-B.1. Purification and properties. Biochem. J., 277, 887-890.

81. Schouten, S.; Baas, M.; Hopmans, E.C.; Reysenbach, A.L.; Damste, J.S.S. (2008). Tetraether membrane lipids of Candidatus "Aciduliprofundum boonei", a cultivated obligate thermoacidophilic euryarchaeote from deep-sea hydrothermal vents. Extremophiles, 12, 
119-124.

82. Seiboth, B.; Hartl, L.; Pail, M.; Fekete, E.; Karaffa, L.; Kubicek, C.P. (2004). The galactokinase of Hypocera jecorina is essential for cellulase induction by lactose but dispensable for growth on D-lactose. Mol. Microbiol., 51, 1015-1025.

83. Singh, S.P.; Purohit, M.K.; Aoyagi, C.; Kitaoka, M.; Hayashi, K. (2010). Effect of growth temperature, induction and molecular chaperones on the solubilization of over-expressed cellobiose phosphorylase from Cellvibrio gilvus under in-vivo conditions. Biotechnol. Bioproc. Engin., 15(2), 273-276.

84. Strauss, J.; Mach, R.L.; Zeilinger, S.; Hartler, G.; Stoffler, G.; Wolschek, M.; Kubicek, C.P. (1995). Cre1, the carbon catabolites repressor protein from Trichoderma reesei. FEBS Letts., 376, 103-107.

85. Sujatha, P.; Bapi, R.; Ramana, T. (2005). Studies on a new marine streptomycete BT-408 producing polyketide antibiotic SBR-22 effective against methicillin resistant Staphylococcus aureus. Microbiol. Res., 160(2), 119-126.

86. Sukumaran, R.K.; Singhania, R.R.; Pandey, A. (2005). Microbial cellulases-production, applications and challenges. J. Sci. Ind. Res., 64, 832-844.

87. Suto, M.; Tomita, F. (2001). Induction and catabolic repression mechanisms of cellulase in fungi. J. Biosci. Bioeng., 92, 305-311.

88. Svetlana, V.; Karthik, A.; Eunkyoung, S.; Behnam, P. (2008). Treatment of raw cotton fibers with cellulases for non-woven fabrics. Textile Res. J., 78(6), 540-548.

89. Tansey, M.R. (1971). Agar diffusion assay of cellulolytic ability of thermophilic fungi. Archive fur Mikrobiologie, 77(1), 1-11.

90. Tarek, A.A.M.; Nagwa, A.T. (2007). Optimization of cellulase and glucosidase induction by sugarbeet pathogen Sclerotium rolfsii. Afr. J. Biotechnol., 6(8), 1048-1054.

91. Tehei, M.; Zaccai, G. (2005). Adaptation to extreme environments: macromolecular dynamics in complex systems. Biochim. Biophy. Acta., 1724(3), 404-410.

92. Tengerdy, R.P. (1996). Cellulase production by solid substrate fermentation. J. Sci. Ind. Res., 55, 313-316.

93. Van wyk, J.; Mogale, A.; Seseng, T. (2001). Bioconversion of wastepaper to sugars by cellulase from Aspergillus niger, Trichoderma viride and Penicillium funiculosum. J. Solid Waste Technol. Manag., 27, 82-86.

94. Vieille, C.; Zeikus, G. (2001). Hyperthermophilic enzymes: sources, uses, and molecular mechanisms for thermostability. Microbiol. Mol. Biol. Rev., 65(1), 1-43

95. Walsh, G.; Headon, D. (1994). Protein Biotechnology. Chicester, Wiley, UK.

96. Zacchi, G.; Skoong, K.; Hahn-Hagerdal, B. (1988). Economic evaluation of enzymatic hydrolysis of phenol pretreated wheat straw. Biotechnol. Bioengi., 32, 460-468

97. Zerbini, J.E.; Oliveira, E.M.M.; Bon, E.P.S. (1999). Lignin peroxidase production by Streptomyces viridosporus T7A: Nitrogen nutrition optimization using glucose as carbon source. Appl. Biochem. and Biotechnol., 77-79, 681-688.

98. Zhang, Y.H.P.; Himmel, M.E.; Mielenz, J.R. (2006). Outlook for cellulase improvement: screening and selection strategies. Biotechnology Advances, 24, 452-481.

99. Zhou, L.; Yeung, K.; Yuen, C. (2001). Combined cellulase and wrinkle free treatment on cotton fabric. J. Dong Hua University, 18, 11-15.

100. Zverlov, V.; Riedel, K.; Bronnenmeier, K. (1998). Properties and gene structure of a bifunctional cellulytic enzyme (CelA) from the extreme thermophile Anaerocellum thermophilum with separate glycosyl hydrolase family 9 and 48 catalytic domains. Microbiology, 144, 457465 . 